Kredo 3 (2020)
KREDO: Jurnal Ilmiah Bahasa dan Sastra
Terakreditasi Sinta 4 berdasarkan Keputusan Direktorat
Jenderal Penguatan Riset dan Pengembangan,
Kementerian Riset, Teknologi dan Pendidikan Tinggi
Republik Indonesia
Nomor: 23/E/KPT/2019. 08 Agustus 2019
https://jurnal.umk.ac.id/index.php/kredo/index

\title{
KEEFEKTIFAN PENGGUNAAN TEKNIK PREP TECHNIQUE DALAM KETERAMPILAN MEMBACA PEMAHAMAN CERPEN SISWA KELAS IX SMP NEGERI 3 BABAT TOMAN KABUPATEN MUSI BANYUASIN
}

\author{
Yesi Susanti $^{1}$, Siti Rukiyah ${ }^{2}$, Arif Ardiansyah ${ }^{2}$ \\ Email: yesis0036@gmail.com
}

Program Studi Pendidikan Bahasa dan Sastra Indonesia

Fakultas Keguruan dan Ilmu Pendidikan Universitas PGRI Palembang

Info Artikel

Sejarah Artikel

Diterima 7 Maret 2020

Disetujui $15 \mathrm{Mei}$

2020

Dipublikasikan 20

Mei 2020

Keywords

understanding short stories, prep technique techniques Kata Kunci pemahaman cerpen, teknik prep technique

\section{Abstract}

The problem in this study is how the effectiveness of the use of the Prep Technique technique in understanding short stories of class IX students of SMP Negeri 3 Babat Toman, Musi Banyuasin Regency. The purpose of this study was to determine and describe the effectiveness of the use of the Prep Technique technique in understanding the short stories of IX students of SMP Negeri 3 Babat Toman, Musi Banyuasin Regency. The research data was obtained through a test technique that is an objective test. Data analysis techniques used include validity and reliability testing. Based on the results of analysis of student test data obtained that "tcount" is greater than "ttable" if tcount $\geq$ then Ho is rejected and Ha is accepted if tcount $\geq$ ttable then Ha is accepted Ho is rejected based on the above tcount calculation turns out tcount $=0.953 \geq$ ttable $=0.268$ at the significance level $99 \%$ means the effectiveness of the use of the Prep Technique technique in understanding the short stories : of IX students of SMP Negeri 3 Babat Toman, Musi Banyuasin Regency is more effective. Abstrak

Masalah dalam penelitian ini adalah bagaimanakah tingkat keefektifan penggunaan teknik Prep Technique dalam keterampilan membaca pemahaman cerpen siswa kelas IX SMP Negeri 3 Babat Toman Kabupaten Musi Banyuasin. Tujuan penelitian ini untuk mengetahui dan mendeskripsikan tingkat keefektifan penggunaan teknik Prep Technique dalam keterampilan : membaca pemahaman cerpen siswa IX SMP Negeri 3 Babat Toman Kabupaten Musi Banyuasin. Data penelitian ini diperoleh melalui teknik tes yaitu tes objektif. Teknik analisis data yang digunakan meliputi uji validitas dan uji raliabilitas. Berdasarkan hasil analisis data tes siswa

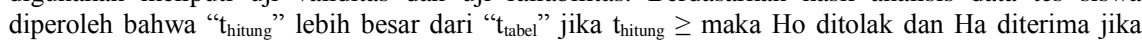
$\mathrm{t}_{\text {hitumg }} \geq \mathrm{t}_{\text {tabel }}$ maka Ha diterima Ho ditolak berdasarkan perhitungan $\mathrm{t}_{\text {hitung }}$ diatas ternyata $\mathrm{t}_{\text {hitung }}=0,953$ $\geq \mathrm{t}_{\text {tabel }}=0,268$ pada taraf signitifikan $99 \%$ berarti keefektifan penggunaan teknik Prep Technique dalam keterampilan membaca pemahaman cerpen siswa IX SMP Negeri 3 Babat Toman Kabupaten Musi Banyuasin lebih efektif. 


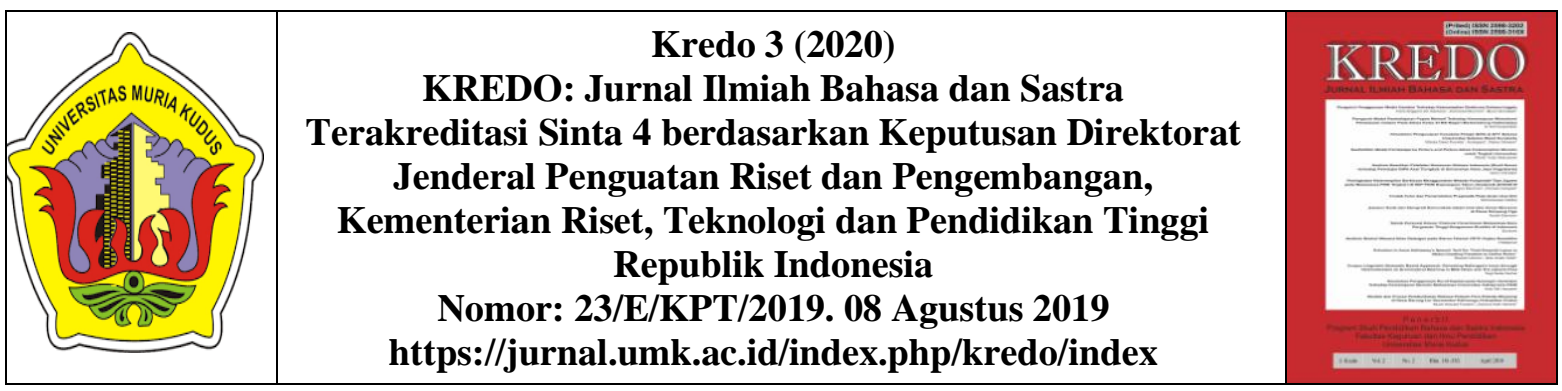

\section{PENDAHULUAN}

Karya sastra adalah hasil dari ilmu sastra berupa karya seni bermedia atau berbahan utama bahasa. Karya sastra diciptakan untuk dinikmati, dipahami, dirasakan, dan dimanfaatkan oleh pembaca. Masyarakat mengenal karya sastra sebagai wadah untuk menyampaikan dan menuangkan ide-ide penulis kepada pembaca melalui bahasa tulis seperti, puisi, cerpen, novel, roman, drama, dan lain-lain. Karya sastra memiliki fungsi untuk menyampaikan ide-ide atau gagasan seseorang seperti puisi, prosa dan drama..

Salah satu bentuk karya sastra yaitu cerpen. "Cerpen merupakan bentuk prosa yang relatif pendek, kata pendek dalam batasan ini tidak jelas ukurannya, dikatakan pendek juga karena genre ini hanya mempunyai efek tunggal, karakter, plot, dan yang terbatas, tidak beragam dan tidak kompleks" (Sumardjo, 2008:30). Sementara menurut pendapat Sedgwick (dikutip Tarigan, 2011:179) “Cerpen adalah penyajian suatu keadaan tersendiri atau suatu kelompok keadaan yang memberikan kesan yang tunggal pada jiwa pembaca."

Berdasarkan beberapa pendapat di atas, penulis dapat menyimpulkan bahwa yang dimaksud cerpen adalah salah satu karya sastra bagian dari prosa berupa cerita rekaan yang dibaca sekali habis yang memiliki ruang lingkup kecil, padat, lengkap dan singkat serta ditulis berdasarkan peristiwa kehidupan manusia yang dapat menimbulkan efek perasaan pada pembacanya.

Untuk membaca cerpen terdapat berbagai strategi, metode dan teknik yang telah ditentukan. Salah satu teknik yang digunakan adalah teknik Prep 296 | Jurnal Kredo

Vol. 3 No. 2 April 2020
Technique. Teknik Prep Technique adalah teknik untuk memperoleh pengetahuan siswa dalam membaca. Teknik ini dapat memperluas pemahaman siswa untuk menyiapkan pembelajaran teks yang akan dibaca. Penggunaan teknik Prep Technique mengandung dua kegiatan yaitu: melibatkan siswa dalam diskusi kelompok dan menganalisis tanggapan siswa. Melibatkan siswa dalam diskusi kelompok adalah siswa diarahkan melakukan curah pendapat dengan beberapa pertanyaan, hal ini dimaksud untuk mendorong siswa dalam meningkatkan keterampilan berdiskusi, agar diskusi berjalan dengan lancar. Menganalisis tanggapan siswa kegiatan ini memberikan kesempatan kepada siswa untuk memperoleh informasi.

Dari beberapa pendapat di atas, dapat disimpulkan teknik Prep Technique dapat digunakan untuk meningkatkan pengetahuan siswa dalam berdiskusi kelompok. Guru tersebut untuk mendorong imajinasi siswa dalam melakukan curah pendapat dan secara langsung menjelaskan apa yang akan siswa diskusikan.

Alasan peneliti memilih teknik Prep Technique dalam keterampilan membaca cerpen karena dengan meningkatkan pengetahuannya dalam berdiskusi kelompok. Teknik ini digunakan untuk membantu siswa lebih efektif dalam berdiskusi. Bagi siswa yang hanya mengetahui sedikit tentang suatu topik, teknik ini dapat membantu memperluas pemahaman siswa dalam menyiapkan pembelajaran teks yang akan dibaca pada saat berdiskusi. Secara sistematis sehingga siswa memahami materi yang akan di didiskusikan pada materi pembelajaran membaca cerpen. 


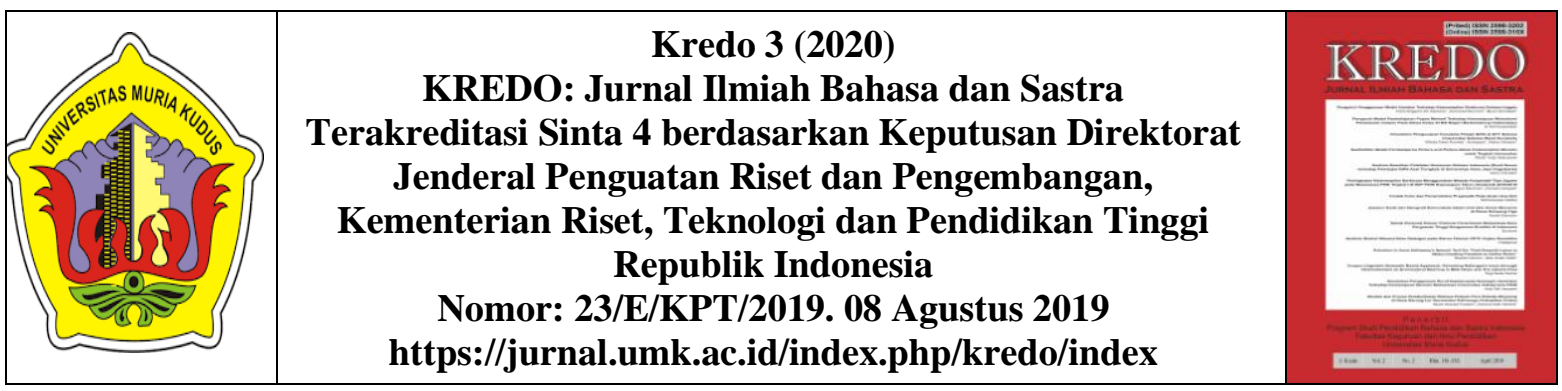

Penulis memilih dan menetapkan SMP Negeri 3 Babat Toman Kabupaten Musi Banyuasin sebagai objek atau tempat peneliti ini berdasarkan alasan SMP Negeri 3 Babat Toman Kabupaten Musi Banyuasin sudah menerapkan kurikulum 2013. Melihat kondisi tersebut sebagai alasan untuk menerapkan pembelajaran teknik Prep Technique dalam keterampilan membaca pemahaman cerpen sebagai upaya meningkatkan keefektifan siswa dalam membaca cerpen pada siswa SMP Negeri 3 Babat Toman Kabupaten Musi Banyuasin teknik pembelajaran ini memungkinkan siswa untuk belajar lebih aktif dari yang sebelumnya dan mencari konsep-konsep atau penyelesaian.

\section{KAJIAN TEORI}

\section{Pengertian Keterampilan Membaca}

Dalam pembelajaran bahasa terdapat empat keterampilan berbahasa. Keempat keterampilan tersebut adalah keterampilan menyimak, keterampilan berbicara, keterampilan membaca, dan keterampilan menulis. Keterampilan membaca merupakan suatu proses yang dilakukan serta dipergunakan oleh pembaca untuk memperoleh pesan, yang hedak disampaikan oleh penulis melalui media kata-kata/bahasa tulis. Selain itu membaca juga merupakan upaya untuk memahami makna dari apa yang tertulis dalam teks. Oleh karena itu membaca perlu menguasai bahasa yang dipergunakannya dengan membaca juga dapat memperoleh ilmu pengetahuan.

Keterampilan membaca merupakan sebuah usaha untuk mengetahui dan memperoleh ilmu pengetahuan. Dengan membaca dapat menyerap informasi dari suatu bacaan dengan benar dan lengkap. Semakin banyak informasi yang dibaca semakin banyak informasi yang dikuasai melalui surat kabar, majalah dan buku. "Membaca terdiri dari keterampilan membaca yang saling berkaitannya (inter-related reading skills). Keterampilan-keterampilan ini terdiri dari keterampilan pokok (macro-skills) dan mi-cro-skills sebagai bagian-bagiannya." (Johan, 2012:1).

Menurut Olivia (2008:3) sebagai berikut. Membaca adalah salah satu proses yang sangat peting untuk mendapatkan ilmu pengetahuan. Tanpa membaca manusia dapat dikatakan tidak bisa hidup di zaman sekarang ini karena hidup manusia sangat tergantung pada ilmu pengetahuan yang dimilikinya, dan untuk mendapatkan ilmu pengetahuan itu, salah satunya dengan cara membaca.

Menurut Kamus Besar Bahasa Indonesia (KBBI, 2008:109) "membaca adalah melihat serta memahami isi dari apa yang tertulis dengan melisankan atau hanya di dalam hati." Dari beberapa pendapat di atas, dapat disebutkan bahwa keterampilan membaca merupakan suatu kegiatan memahami isi, ide atau gagasan baik yang tersurat maupun tersirat dalam bahan bacaan, sehingga dapat diambil makna dari pesan yang hendak disampaikan oleh penulis.

\section{Tujuan Membaca}

Tujuan membaca dianggap juga sebagai modal dalam membaca. Bahkan menurut hasil penelitian, hubungan antra tujuan membaca dengan kemampuan membaca sangat penting. Adapun tujuan membaca adalah untuk mencari serta memperoleh informasi dengan memahami isi bacaan. Tarigan (2008:9) mengekemukakan beberapa hal penting mengenai tujuan membaca sebagai berikut. 


Kredo 3 (2020)
KREDO: Jurnal Ilmiah Bahasa dan Sastra
Terakreditasi Sinta 4 berdasarkan Keputusan Direktorat
Jenderal Penguatan Riset dan Pengembangan,
Kementerian Riset, Teknologi dan Pendidikan Tinggi
Republik Indonesia
Nomor: 23/E/KPT/2019. 08 Agustus 2019
https://jurnal.umk.ac.id/index.php/kredo/index

1) Membaca untuk menemukan atau mengetahui penemuan-penemuan yang telah dilakukan oleh tokoh apa yang telah dibuat oleh tokoh.

2) Membaca untuk mengetahui urutan atau susunan, organisasi cerita.

3) Membaca untuk menemukan atau mengetahui apa yang terjadi pada setiap bagian cerita. Membaca untuk menemukan serta megetahui mengapa para tokoh merasakan apa yang hendak diperlihatkan oleh pengarang kepada para pembaca.

4) Membaca untuk menemukan serta mengetahui apa-apa yang tidak biasa, tidak wajar mengenai seseorang tokoh, apa yang lucu dalam cerita, atau apakah cerita itu benar atau tidak benar.

5) Membaca untuk menemukan apakah tokoh berhasil ata hidup dengan ukuran -ukuran tertentu.

6) Membaca untuk menemukan bagaimana caranya tokoh berubah.

Nurhadi (2016:24) mengemukakan bermacam-macam variasi tujuan membaca sebagai berikut.

1) Membaca untuk memperoleh kesan umum dari suatu buku, artikel atau tulisan singkat, dan menentukan halhal tertentu dari suatu bahan baca.

2) Membaca dengan tujuan ingin menjadi lebih baik dibandigkan dengan orang lain dalam lingkungan pergaulannya.

3) Membaca untuk mendapatkan kekuatan keyakinan pada partai politik yang kita anut, memperkuat keyakinan agama, mendapatkan nilai-nilai baru dari sebuah buku filsafat, dan sebagainya.

4) Membaca untuk mendapatkan sensasi-sensasi baru melalui penikmatan emosional bahan

298 | Jurnal Kredo

Vol. 3 No. 2 April 2020 bacaan (buku cerita, novel, roman, cerita pendek, cerita kriminal biografi tokoh terkenal, dan sebagainya).

5) Membaca untuk menghindari diri dari kesulitan, ketakutan, atau penyakit tertentu.

Berdasarkan pendapat di atas dapat disimpulkan bahwa tujuan membaca adalah untuk memperoleh informasiinformasi yang ada didalam sebuah tulisan, memahami isi dan makna secara luas, dan juga dapat menambah pengetahuan.

\section{Membaca Pemahaman}

Kemampuan membaca sangatlah kompleks dan bukan hanya kemampuan teknik membacanya saja melainkan juga kemampuan dalam memahami bacaan.. Membaca pemahaman bertujuan untuk memahami isi bacaan. Johan (2012:9) membaca pemahaman merupakan "sejenis membaca yang bertujuan untuk memahami standar-standar atau norma kesastraan, resensi kritis, drama tulis, serta pola-pola fiksi."

Berdasarkan pendapat di atas dapat disimpulkan bahwa membaca pemahaman adalah kegiatan membaca untuk memahami isi bacaan secara keseluruhan, baik yang tersirat maupun yang tersurat dari bahan bacaan.

\section{Pengertian Cerpen}

"Sastra merupakan sebuah karya sastra untuk menyampaikan kritik sosial kepada masyarakat dengan menggunakan medium bahasa" (Yasa, 2012:4). Sementara menurut Wardarita (2015:53), "karya sastra adalah karya yang ditulis oleh pengarang yang tidak terlepas dari sejarah sastra dan latar belakang sosial budayanya." 


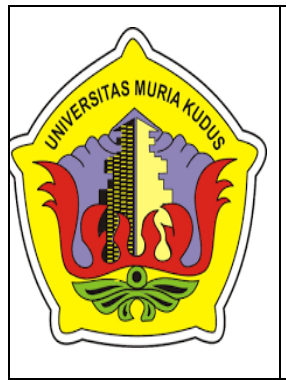

Kredo 3 (2020)

KREDO: Jurnal Ilmiah Bahasa dan Sastra

Terakreditasi Sinta 4 berdasarkan Keputusan Direktorat

Jenderal Penguatan Riset dan Pengembangan,

Kementerian Riset, Teknologi dan Pendidikan Tinggi

Republik Indonesia

Nomor: 23/E/KPT/2019. 08 Agustus 2019

https://jurnal.umk.ac.id/index.php/kredo/index

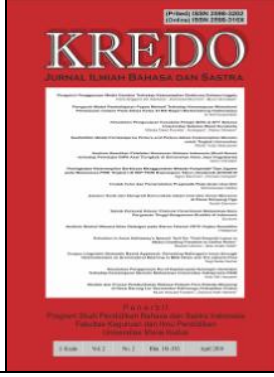

Akan tetapi, karya sastra juga tidak akan mempunyai makna tanpa ada pembaca. Oleh karena itu, seluruh situasi yang berhubungan dengan karya sastra itu harus diperhatikan dalam pemaknaan karya sastra. Salah satu bentuk karya sastra yaitu cerpen. "Cerpen adalah cerita yang paling banyak digemari dunia kesastraan indonesia sesudah perang dunia kedua. " (Rosidi dikutip Tarigan, 2011:180).

"Cerpen adalah cerita berbentuk prosa yang relatif pendek. Pendek di sini dapat dibaca sekali duduk dalam waktu kurang dari satu jam, dikatakan pendek juga karena genre ini hanya mempunyai efek tunggal, karakter, plot, dan setting yang terbatas, tidak beragam dan tidak kompleks" (Sumardjo dikutip Tarigan, 2011:182).

Adapun ciri-ciri cerpen Tarigan (2011:180-181), sebagai berikut.

1) Ciri -ciri utama cerpen adalah singkat, padat, dan intensi.

2) Unsur utama cerpen adalah adegan, tokoh dan gerak.

3) Bahasa cerpen harslah tajam, sugesti dan menarik perhatian

4) Cerpen harus mengandung konsepsi mengenai kehidupan, baik secara langsung maupun tidak langsung.

5) Sebuah cerpen harus menimbulkan satu efek dalam pikiran membaca.

6) Cerpen harus menimbulkan perasaan pada pembaca.

7) Cerpen mengandung detail-detail dan insiden-inside.

8) Sebuah cerpen harus menguasai jalan cerita.

9) harus mempuyai seorang pelaku utama.

10) Cerpen harus mempuyai satu efek atau kesan yang menarik.
11) Cerpen tergantung pada (satu) situasi.

12) Cerpen memberi impresi tunggal.

13) Cerpen memberikan suatu kebulatan efek.

14) Cerpen menyajikan satu emosi .

15) Jumlah kata yang terdapat dalam cerpen biasanya 10.000 kata, tidak boleh lebih dari 10.000 kata (atau kira-kira 33 halaman kuarto spasi rangkap).

Berdasarkan beberapa pendapat-pendapat tersebut dapat disimpulkan, penulis dapat menyimpulkan bahwa yang dimaksud cerpen adalah salah satu jenis karya sastra yang memaparkan kisah atau cerita manusia beserta seluk beluknya lewat tulisan pendek dan singkat.

\section{Unsur-Unsur Cerpen}

Berdasarkan unsur-unsurnya, cerpen dibangun dua unsur yaitu unsur intrinsik dan ekstrensik. Unsur-unsur intrinsik merupakan unsur yang membangun sebuah karya sastra dari dalam yang mewujudkan struktur suatu karya sastra, seperti: tema, tokoh, penokohan, alur dan lain-lainnya. Menurut Sutopo (2008:7), ada enam unsur intrinsik cerpen sebagai berikut.

\section{a. Tema}

"Tema adalah ide sebuah cerita/gagasan pokok yang diangkat sebagai ide cerita. Misalnya kesetiakawanan, persahabatan, percintaan, dan sebagainya. Tema bisa berwujud pengamatan pengarang terhadap kehidupan. Kesimpulannya atau bahkan hanya bahan mentah pengamatannya saja" (Sutopo, 2008:7). Sementara menurut Sumardjo (2008:56) "tema adalah dasar sebuah cerita atau pandangan hidup yang membangun 


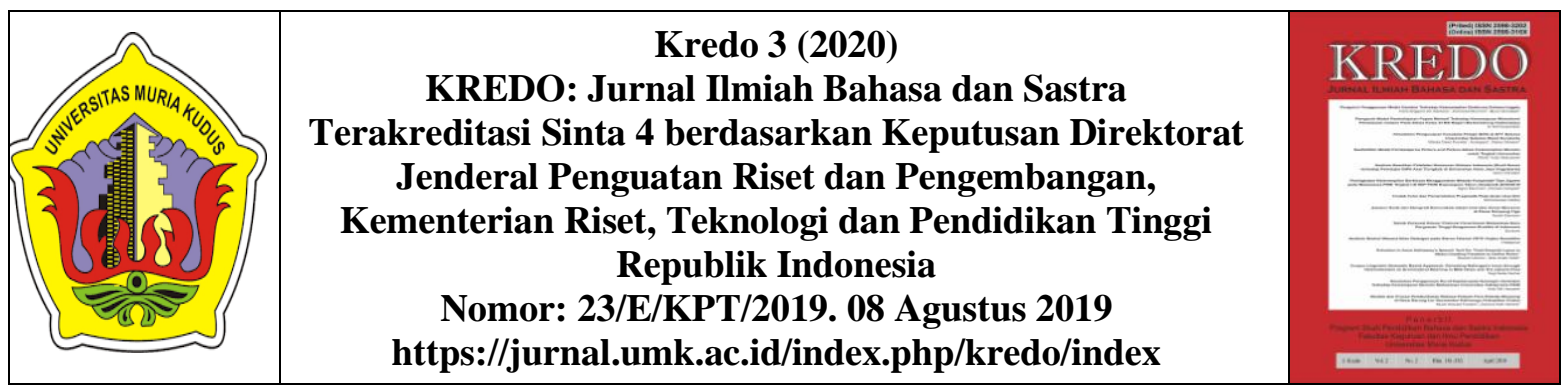

gagasan utama dalam sebuah karya sastra."

Dari beberapa pendapat di atas, dapat disimpulkan bahwa tema merupakan gagasan utama yang mendasari dari jalan cerita yang melatar belakangi suatu cerita.

\section{b. Alur}

Alur adalah jalan cerita dibangun atas jalinan peristiwa yang sambung menyambung membentuk satu kesatuan cerita" (Sutopo, 2008:9). Sementara menurut Sumardjo (2008:49) "alur adalah Jalan cerita memang tak terpisahkan yang harus dibedakan dari suatu kejadian karena ada sebabnya, yang mengerakkan kejadian cerita tersebut."

Dari pendapat di atas, dapat disimpulkan alur merupakan keseluruhan rangkaian peristiwa yang terdapat dalam cerita, alur tidak hanya dapat diihat dari jalannya suatu peristiwa.

\section{c. Tokoh dan Penokohan}

"Tokoh Dan Penokohan merupakan hal yang menarik dalam sebuah cerita berupa konflik atau perbedaan karakter para tokoh. Pemberian karakter tokoh atau pelaku dapat dilakukan secara langsung dan tidak langsung" (Sutopo, 2008:7). Sementara Sumardjo (2008:65), menyatakan " tokoh dan penokohan merupakan cerita yang harus kita gambarkan sebagus mungkin. Maka apa yang diucapkannya, apa yang diperbuatnya, apa yang dipikirkannya, apa yang dirasakan-nya harus betul-betul menunjang penggambaran wataknya yang khas milik dia."

Berdasarkan pendapat di atas, dapat disimpulkan bahwa tokoh dan penokohan merupakan cara pengarang

300 | Jurnal Kredo

Vol. 3 No. 2 April 2020 menggambarkan karakter tokoh-tokoh dalam cerita.

\section{d. Setting \\ Setting berhubungan dengan} masalah kapan terjadinya peristiwaperistiwa yang diceritakan dalam sebuah karya fiksi. Menurut Sumardjo (2008:75) " setting adalah tempat terjadinya sebuah cerita, kapan terjadinya cerita, dan terjadinya cerita di suatu tempat dalam satu waktu, yang harus ada tempat dan ruang kejadiannya."

Dari pendapat di atas, dapat disimpulkan setting merupakan keterangan dari waktu, ruang dan suasana terjadinya peristiwa di dalam cerita. Setting berhubungan erat dengan pelaku (tokoh) dalam suatu peristiwa. Oleh sebab itu, setting sangat mendukung jalan cerita.

\section{e) Amanat}

"Selain berkarya, pengarang cerita berupaya menyampaikan pesan moral kepada pembaca cerita melalui amanat cerita. Amanat adalah pesan yang disampaikan sendiri oleh pembaca" (Sutopo, 2008:9). Sementara menurut Sumardjo (2008:119) "amanat adalah bagian akhir kesan dari cerita yang dibaca. Dalam hal ini, pengarang menitipkan nilai-nilai kehidupan yang dapat diambil dari cerpen yang dibaca. Amanat memperluas, bagaimana sang pembaca memahami cerpen yang baca."

Dari pendapat di atas, dapat disimpulkan amanat adalah pesan moral yang ingin disampaikan penulis kepada pembaca yang diambil dalam nilai kehidupan cerpen yang dibaca.

\section{f. Gaya Bahasa}

Gaya Bahasa merupakan cerita yang dikemas secara sederhana menjadikan 


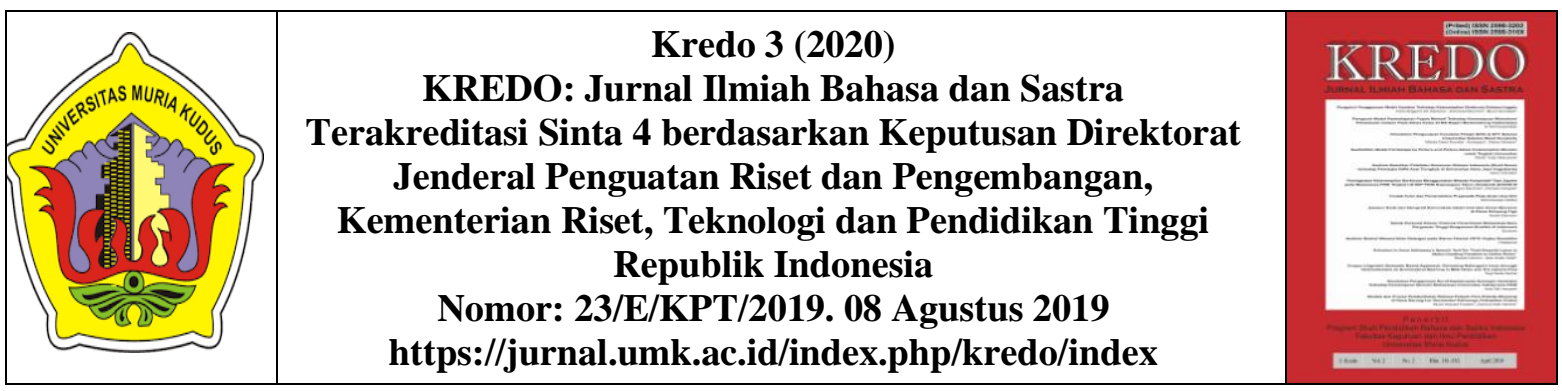

cerpen mudah dipahami. Kesederhanaan ini tidak membosankan karena keseluruhan cerita lebih banyak didominasi dengan pertanyaanpertanyaan yang menarik (Priyatni, 2010:55). Sementara Sumardjo (200892) "gaya bahasa merupakan cara seseorang mengungkapkan persoalan yang ada di dalam cerpen tersebut."

Dari pendapat di atas, dapat disimpulkan gaya bahasa merupakan persoalan yang diangkat di dalam sebuah cerita di dalam cerpen yang dikemas secara sederhana dan mudah dipahami oleh orang lain.

\section{Pengertian Teknik Prep Technique (Diskusi)}

Teknik diskusi adalah sebelum diskusi siswa terlebih dahulu membaca apa yang akan diskusikan nanti agar siswa dapat memperoleh pengetahuan yang mendalam. Teknik diskusi ini dapat menjadi sarana bagi guru dan mempersiapkan siswa sebagai titik awal dalam memahami bacaan dengan baik (Tierey dikutip Eka 1990:39). Selanjutnya Zuchdi, (2008:144). Teknik diskusi merupakan kegiatan sebelum membaca yang dapat membantu mengaktifkan pengetahuan siswa dalam berduskusi kelompok melalui interaksi tatap muka, dimana setiap anggota mendapatkan kesempatan untuk menyumbangkan ide atau gagasan dari topik yang akan dibahas dengan menguasai isi pelajaran berdasarkan pengetahuan dan pengalaman dalam memecahkan suatu masalah yang dimana guru memberikan suatu persoalan masalah kepada siswa dan siswa diberikan kesempatan secara bersama-sama untuk memecahkan masalah tersebut. Melalui proses tukar pendapat atau informasi yang sedang dibahas dengan itu dapat melatih siswa menemukan pendapat atau gagasan dari orang lain di dalam diskusi sering terjadi perbedaan pendapat yang bersifat emosional yang tidak terkontrol, akibatnya kadang ada pihak yang merasa tersinggung sehingga dapat menganggu pembelajaran yang akan di diskusikan. Dengan mengunakan Teknik diskusi siswa dituntut belajar lebih efektif dari yang sebelumnya, sambil menganalisis tanggapan siswa sehigga dapat menentukan intruksi berikutnya. Teknik ini dapat digunakan untuk membantu siswa mengetahui seberapa jauh pengetahuan diskusi kelompok siswa sebelum membaca.

Sebelum mempersiapkan siswa membaca cerpen, guru memberikan gambaran untuk merangsang imajinasi atau ide siswa dalam mengarang cerpen yang akan dibaca. Untuk mengetahui cerpen yang akan dibaca, siswa tersebut harus memiliki pengetahuan yang lebih. Hal ini menentukan aktif atau tidak aktifnya siswa dalam berdiskusi. Siswa yang memiliki sedikit tentang bacaan, teknik ini dapat memperluas pemahaman. Penulis memilih dan menetapkan SMP Negeri 3 Babat Toman Kabupaten Musi Banyuasin sebagai objek atau tempat peneliti ini berdasarkan alasan: SMP Negeri 3 Babat Toman Kabupaten Musi Banyuasin sudah menerapkan kurikulum 2013. Dengan Standar kompentensi memahami isi teks bacaan melalui kegiatan membaca pemahaman.

Jadi dapat disimpulkan teknik persiapan diskusi dalam keterampilan membaca pemahaman cerpen merupakan pengembangan dari penelitian tentang pengetahuan awal dan pengetahuan akhir bacaan cepen dalam menciptakan ide-ide serta merumuskan kembali ide-ide 


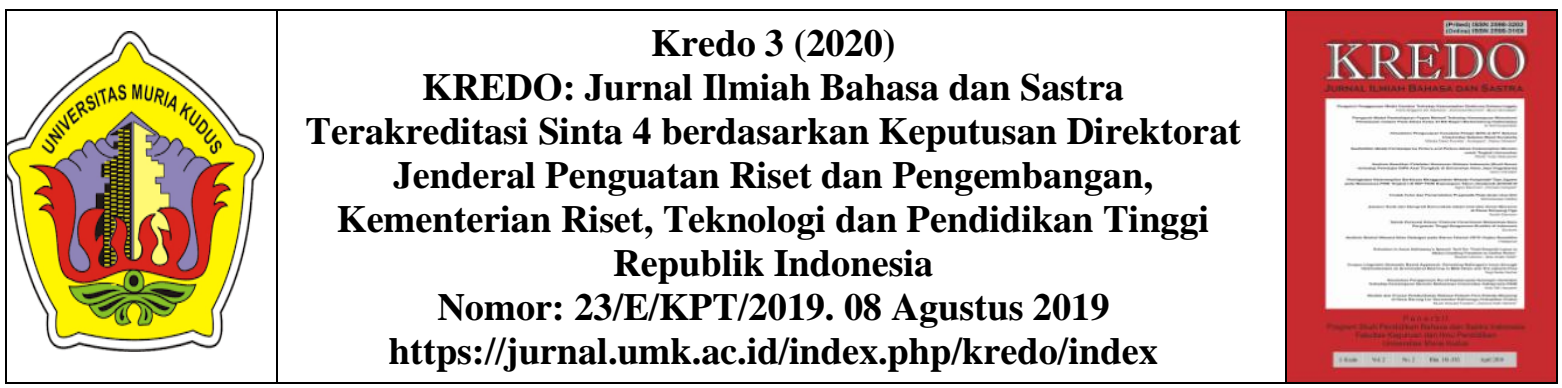

tersebut dan mengarahkan siswa berdiskusi kelompok untuk mencapai tujuan pembelajaran yang dapat dipahami setelah membaca

\section{METODE PENELITIAN}

Metode yang digunakan dalam penelitian ini adalah metode eksperimen. Metode eksperimen dapat diartikan sebagai metode penelitian yang digunakan untuk mencari pengaruh perlakuan tertentu terhadap yang lain dengan kondisi yang terkendalikan. "Metode penelitian eksperimen adalah metode penelitian kuantitatif. Karena metode ini sebagai bagian dari metode kuantitatif mempunyai ciri khas tersendiri, terutama dengan adanya kelompok kontrol.” (Sugiyono, 2016:109). Penelitian ini bertujuan untuk memecahkan atau mejawab permasalahan yang dihadapi agar dapat membuat suatu penggambaran tentang suatu keadaan secara objektif.

\section{Populasi dan Sampel Penelitian Populasi}

Populasi adalah "keseluruhan subjek penelitian. Apabila seseorang ingin semua elemen yang ada dalam wilayah peneliti, maka penelitiannya merupakan penelitian populasi. Studi atau penelitiannya juga disebut studi populasi atau studi sensus." (Arikunto, 2010:173).

Populasi penelitian ini adalah semua siswa kelas IX SMP Negeri 3 Babat Toman Kabupaten Musi Banyuasin yang berjumlah 107 siswa. Jumlah populasi ini dapat dilihat pada tabel 1 berikut.

TABEL 1

POPULASI PENELITIAN

\begin{tabular}{|c|c|c|c|c|}
\hline \multirow{2}{*}{ No. } & \multirow{2}{*}{ Kelas } & $\begin{array}{c}|c| \\
\text { Laki- } \\
\text { laki }\end{array}$ & Perempuan & $\begin{array}{c}\text { Jumlah } \\
\text { Siswa }\end{array}$ \\
\hline 1 & IX 1 & 11 & 16 & 27 \\
\hline
\end{tabular}

302 | Jurnal Kredo

Vol. 3 No. 2 April 2020

\begin{tabular}{|c|c|c|c|c|}
\hline 2 & IX 2 & 11 & 16 & 27 \\
\hline 3 & IX 3 & 12 & 16 & 28 \\
\hline 4 & IX 4 & 10 & 15 & 25 \\
\hline \multicolumn{2}{|c|}{ Jumlah } & 44 & 63 & 107 \\
\hline
\end{tabular}

(Sumber : SMP Negeri 3 Babat Toman

Kabupaten Musi Banyuasin Tahun Ajaran 20182019).

\section{Sampel Penelitian}

"Sampel adalah bagian dari jumlah dan karakteristik yang dimiliki oleh populasi. Teknik pengambilan sampel yang digunakan dalam penelitian ini adalah Radom Sampling (sampel acak), yaitu dengan metode eksperimen." (Sugiyono, 2016:120).

Menurut Arikunto (2010:183) "sampel bertujuan dengan cara mengambil subjek bukan didasarkan atas strata, radom atau daerah tetapi didasari dengan tujuan tertentu." Sesuai dengan penelitian ini, untuk mengetahui keefektifan Penggunaaan Prep Technique dalam keterampilan membaca pemahaman cerpen kelas IX SMP Negeri 3 Babat Toman Kabupaten Musi Banyuasin dalam menemukan gagasan utama pada teks bacaan. Dengan menggunakan metode eksperimen untuk memilih kelas yang dijadikan sampel. Terpilihlah kelas IX 1 sebagai kelas eksperimen dan kelas IX 2 sebagai kelas kontrol. Untuk lebih jelasnya jumlah sampel dari kelas tersebut dapat dilihat pada tabel berikut ini.

TABEL II

SAMPEL PENELITIAN

\begin{tabular}{|c|c|c|c|c|}
\hline \multirow{2}{*}{ No. } & \multirow{2}{*}{ Kelas } & \multicolumn{2}{|c|}{ Siswa } & \multirow{2}{*}{\begin{tabular}{c} 
Jumlah \\
Siswa \\
\cline { 3 - 4 }
\end{tabular}} \\
\cline { 3 - 4 } & IX 1 & 11 & Perempuan & 27 \\
\hline 2 & IX 2 & 11 & 16 & 27 \\
\hline \multicolumn{2}{|c|}{ Jumlah } & 22 & 32 & 54 \\
\hline
\end{tabular}

(Sumber SMP Negeri 3 Babat Toman Kabupaten Musi Banyuasin Tahun Ajaran 2018-2019).

\section{Teknik Pengumpulan Data}

Sesuai dengan pendapat Gronlund (dikutip Nurgiyantoro 2016:123) 


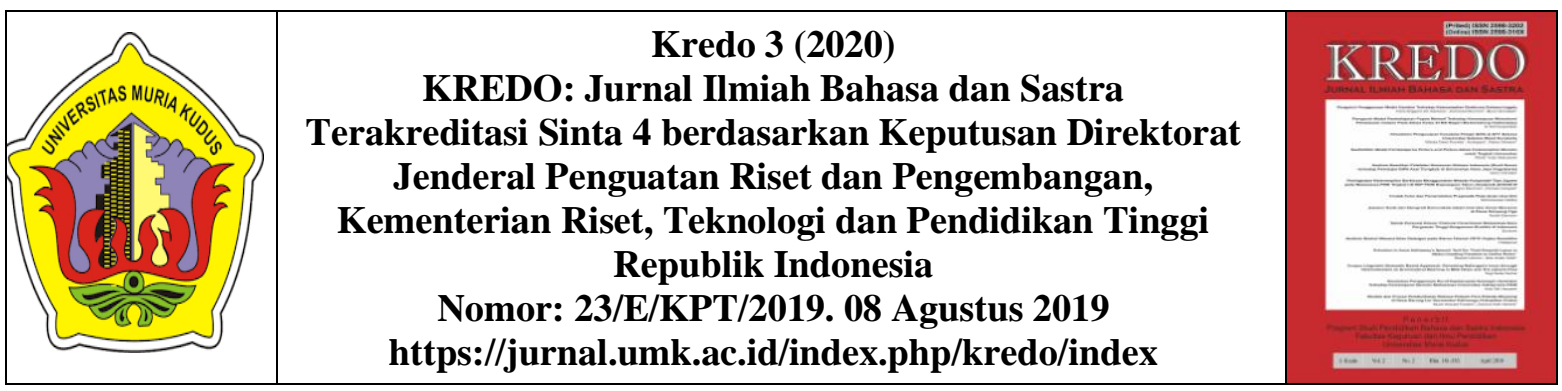

"mengemukakan bahwa tes adalah sebuah instrumen atau prosedur yang sistematis untuk mengukur suatu sampel tingkah laku, misalnya untuk menjawab pertanyaan seberapa banyak teks yang akan dijawab berupa angka" Untuk mengukur kemampuan siswa kelas IX SMP Negeri 3 Babat Toman Kabupaten Musi Banyuasin dalam keterampilan membaca cerpen pemahaman siswa menggunakan tes objektif. Bentuk tes objektif disebut juga sebagai tes jawaban singkat, sesuai dengan namanya, tes jawaban singkat menuntut peserta didik hanya memberikan jawaban singkat, bahkan hanya dengan memiliki kodekode tertentu yang mewakili alternatif jawaban yang telah disediakan, misalnya dengan memberikan tanda silang, melingkari, atau menghitamkan opsi jawaban pilih.

\section{Teknik Analisis Data}

Analisis data merupakan salah satu langkah yang sangat penting dalam kegiatan penelitian. Analisis data bertujuan untuk menyajikan data sesuai dengan tujuan peneliti dan melakukan perhitungan untuk menjawab rumusan dan hipotesis peneliti dengan menggunakan statistik kuantitatif.

Langkah-langkah analisis data dalam penelitian ini sebagai berikut.

a. Mengolah data, data yang sudah terkumpul kemudian perlu diolah kembali dengan tujuan agar data lebih mudah, sehingga semua data yang telah terkumpul akan di persiapkan dengan sebaik mungkin dan disusun dengan rapi kemudian baru dikembangkan.

b. Penyuntingan merupakan kegiatan pemeriksaan seluruh daftar pertanyaan yang dikeluarkan dari responden.
Data penelitian ini diperoleh melalui teknik tes yaitu tes objektif. Teknik analisis data yang digunakan meliputi uji validitas dan uji raliabilitas. Berdasarkan hasil analisis data tes siswa diperoleh bahwa " $t_{\text {hitung }}$ " lebih besar dari " $t_{\text {tabel }}$ " jika $t_{\text {hitung }} \geq$ maka Ho ditolak dan Ha diterima jika $t_{\text {hitung }} \geq t_{\text {tabel }}$ maka $\mathrm{Ha}$ diterima Ho ditolak berdasarkan perhitungan $t_{\text {hitung }}$ diatas ternyata $t_{\text {hitung }}=$ $0,953 \geq \mathrm{t}_{\text {tabel }}=0,268$ pada taraf signitifikan $99 \%$ berarti keefektifan penggunaan teknik Prep Technique dalam pemahaman cerpen siswa IX SMP Negeri 3 Babat Toman Kabupaten Musi Banyuasin.

\section{HASIL DAN PEMBAHASAN}

Berdasarkan hasil tes siswa, dapat diinterpretasikan bahwa keberhasilan siswa di kelas ekperimen dalam keterampilan membaca pemahaman cerpen ditunjang oleh beberapa faktor pendukung yaitu siswa kelas IX.1 SMP Negeri 3 Babat Toman sebagai kelas eksperimen maupun dengan menggunakan teknik Prep Technique dengan menggunakan model discovery learning siswa tidak mengalami kesulitan dalam keterampilan membaca pemahaman cerpen menggunakan teknik Prep Technique. Teknik Prep Technique sangatlah efektif digunakan dalam keterampilan membaca pemahaman cerpen karena dapat meningkatkan kemampuan siswa membaca cerpen sangat baik dan benar.

Alat ukur berupa tes untuk mengetahui meningkatkan keefektifan siswa dalam membaca cerpen pembelajaran ini memungkinkan siswa untuk belajar lebih aktif dari yang sebelumnya. 


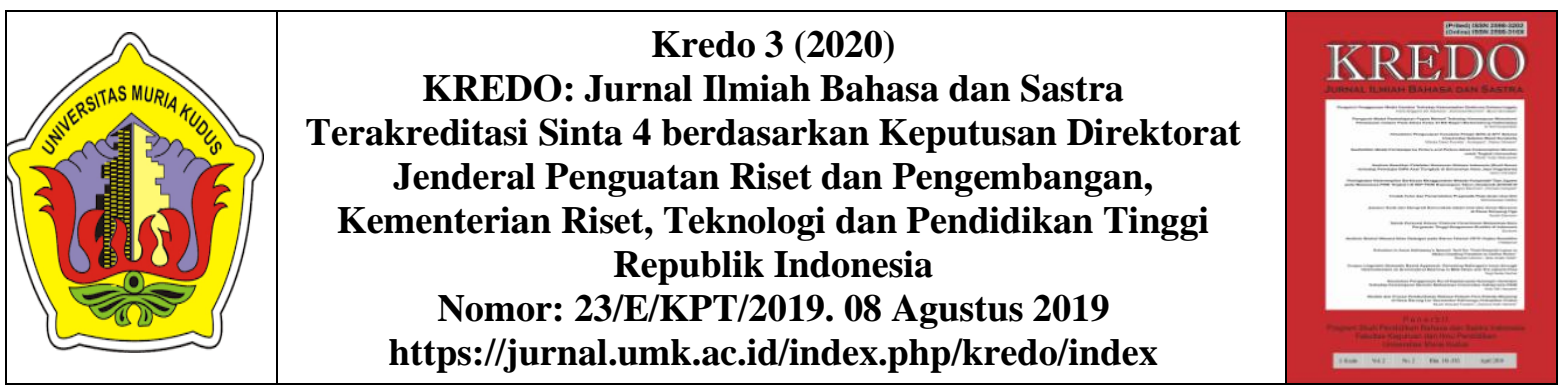

Keberhasilan siswa dalam membaca pemahaman cerpen memberikan manfaat yang benar bagi siswa. Dengan kemampuan membaca pemahaman cerpen siswa dapat mengemukakan pikiran, ide, isi dan gagasan. Oleh karena itu, guru hendaknya berusaha meningkatkan keterampilan membaca pemahaman cerpen menggunakan teknik Prep Technique yang sesuai dengan materi dan tujuan pembelajaran.

Pembahasan hasil analisis tes siswa dapat dikemukakan, yaitu siswa kelas IX SMP Negeri 3 Babat Toman dalam keterampilan membaca pemahaman cerpen sangat efektif dengan menggunakan teknik Prep Technique. Siswa tidak pernah mengalami kesulitan membaca menggunakan teknik Prep Technique usaha yang dilakukan siswa mengatasi kesulitan menulis adalah banyak berlatih. Guru sering menjelaskan cara menulis dengan baik dan benar. Latihan membaca siswa selalu dinilai oleh guru. Teknik mengajar yang digunakan guru untuk pembelajaran membaca melalui penugasaan, tanya jawab dan diskusi. Buku yang digunakan oleh siswa adalah buku paket dan LKS. Waktu yang digunakan oleh siswa untuk pembelajaran membaca pemahaman cerpen di kelas sudah cukup.

Berdasarkan jawaban tes siswa dapat diinterpretasikan bahwa keberhasilan siswa di kelas ekperimen dalam pembelajaran siswa ditujukan dalam beberapa faktor pendukung yaitu siswa kelas IX.1 SMP Negeri 3 Babat Toman sebagai kelas ekperimen sangat efektif dalam penggunaan teknik Prep Technique, siswa tidak pernah mengalami kesulitan dalam keterampilan membaca pemahaman cerpen. Dengan demikian jika faktor-faktor pendukung 304 | Jurnal Kredo

Vol. 3 No. 2 April 2020 tesebut ditingkatkan, maka keberhasilan pembelajaran membaca pemahaman cerpen di kelas IX SMP Negeri 3 Babat Toman dapat ditingkatkan sehingga siswa mampu membaca secara baik dan benar. Maka siswa dapat menjawab atau mengerjakan soal ulangan semester ataupun ujian-ujian nasional secara benar sehingga nilai bahasa Indonesia siswa dapat meningkat.

Penggunaan teknik Prep Technique merupakan proses belajar, proses yang menerapkan pembelajaran kelompok yang tiap kelompoknya beranggota enam atau delapan orang dengan tuntutan seluruh siswa atau kelompok berperan aktif dalam proses pembelajaran. Dalam penggunaannya, teknik pembelajaran ini merupakan cara belajar yang baru di SMP Negeri 3 Babat Toman Kabupaten Musi Banyuasin pada materi membaca pemahaman cerpen. Sebelum menggunakan teknik Prep Technique, peneliti melakukan observasi terlebih dahulu terhadap siswa yang menjadi sampel peneliti terdiri atas dua kelas masing-masing kelas berjumlah 27 siswa, kelas XI. 1 Sebagai kelas eksperimen dan kelas XI. 2 sebagai kelas kontrol. Penguji dalam penelitian ini dengan cara melakukan tes post-test atau tes awal, sebelum pembelajaran berlangsung dan poste-test akhir, setelah menerapkan teknik ini dalam proses pembelajaran. Penelitian ini dilakukan sebanyak dua kali pertemuan terhadap siswa. Berdasarkan data hasil belajar siswa, didapat nilai rata-rata hasil belajar siswa pada tes post-test kelas XI. I berjumlah 84,07 sebagai kelas eksperimen, sedangkan tes post-test kelas XI. 2 berjumlah 78,14 sebagai kelas kontrol. Dari hasil tersebut, dapat diketahui nilai rata-rata tes post-test 


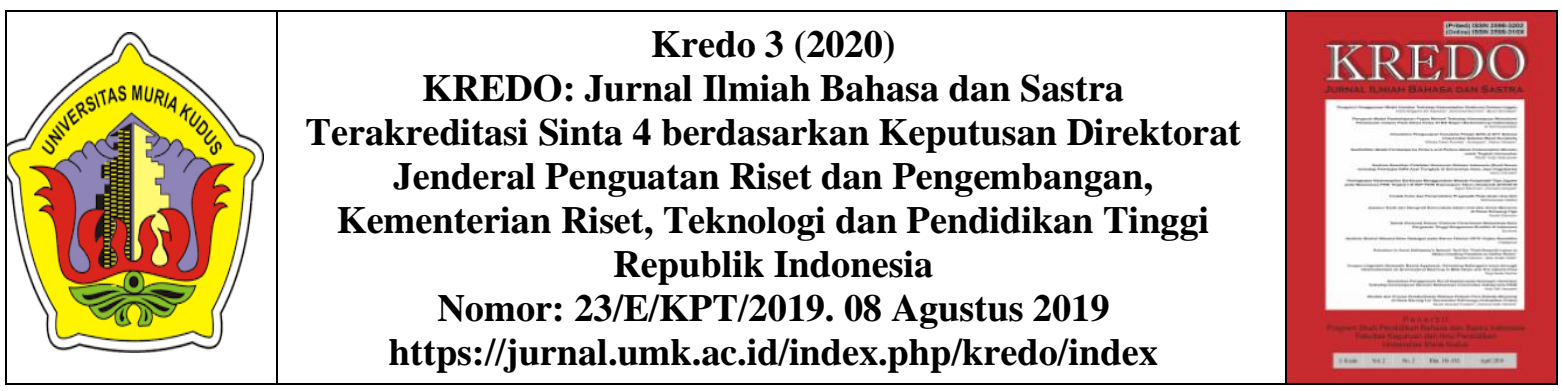

kelas eksperimen lebih besar dari pada post-tes kelas kontrol.

Data penelitian ini diperoleh melalui teknik tes yaitu tes objektif. Teknik analisis data yang digunakan meliputi uji validitas dan uji raliabilitas. Berdasarkan hasil analisis data tes siswa diperoleh bahwa " $t_{\text {hitung }}$ " lebih besar dari " $t_{\text {tabel }}$ " jika $t_{\text {hitung }} \geq$ maka Ho ditolak dan Ha diterima jika $t_{\text {hitung }} \geq t_{\text {tabel }}$ maka Ha diterima Ho ditolak berdasarkan perhitungan $t_{\text {hitung }}$ diatas ternyata $t_{\text {hitung }}=$ $0,953 \geq \mathrm{t}_{\text {tabel }}=0,268$ pada taraf signitifikan $99 \%$ berarti keefektifan penggunaan teknik Prep Technique dalam pemahaman cerpen siswa IX SMP Negeri 3 Babat Toman Kabupaten Musi Banyuasin lebih efektif.

\section{SIMPULAN}

Berdasarkan hasil penelitian dan pembahasan dapat diketahui bahwa penggunaan teknik Prep Technique dengan menggunakan model discovery learning lebih efektif digunakan dalam keterampilan membaca pemahaman cerpen pada siswa kelas IX SMP Negeri 3 Babat Toman. Hal ini dapat dilihat dari hasil post-test kelas eksperimen yang memperoleh nilai 80-90 sebanyak 24 siswa atau bisa dikatakan tuntas dan yang memperoleh nilai 50-70 sebanyak 3 orang siswa atau dikatakan tidak tuntas. Sedangkan hasil post-test kelas kontrol tanpa menggunakan prep technique dalam menggunakan model inquiry learning yang memperoleh nilai 80-100 sebanyak 19 orang siswa atau bisa dikatakan tuntas dan yang memperoleh nilai 50-70 sebanyak 8 orang siswa atau dikatakan tidak tuntas. Sedangkan untuk nilai rata-rata post-test kelas eksperimen sebesar 84,07 dan nilai rata-rata post-test kelas kontrol sebesar 78,14.
Keefektifan teknik Prep Technique tersebut setelah diteliti perbedaannya hasil tes kelas eksperimen dengan hasil tes kelas kontrol dengan menggunakan uji t. Berdasarkan uji t diperoleh bahwa " $t_{\text {hitung }}$ " lebih besar dari " $t_{\text {tabel }}$ " pada taraf signifikan $99 \%$ atau $0,953 \geq 0,268$. Artinya Ho ditolak dan Ha diterima.

Dengan demikian, hipotesis yang penulis kemukakan, yaitu keefektifan penggunaan Prep Technique dengan menggunakan model discovery learning dalam keterampilan membaca pada siswa kelas IX SMP Ngeeri 3 Babat Toman Kabupaten Musi Banyuasin lebih efektif dibandingkan keterampilan membaca pemahaman cerpen tanpa menggunakan teknik Prep Technique dengan menggunakan model inquiry learning.

\section{DAFTAR PUSTAKA}

Arikunto, Suharsimi. 2010. Prosedur Penelitian Suatu Pendekatan Praktik.EdisiRevisi KeVI. Cetakan Ketiga Belas. Jakarta: Rineka Cipta.

Departemen Pendidikan Nasional. 2008. Kamus Besar Bahasa Indonesia.Jakarta: Gramedia Pustaka Pratama.

Mufti, Eka Oktiana. 2012. Keefektifan Penggunaan Prep Technique Dalam Meningkatkan Keterampilan Membaca Pemahaman. Yogyakarta: Universitas Negeri Yogyakarta.

Nurgiantoro, Burhan. 2016. Penilaian Pembelajaran Bahasa Berbasis Kompentensi. $\quad$ Yogyakarta: BPFE.Yogyakarta.

Nurhadi. 2016. Strategi Meningkatkan Daya Baca. Jakarta: Gramedia Pustaka

Pratama. 


Kredo 3 (2020)
KREDO: Jurnal Ilmiah Bahasa dan Sastra
Terakreditasi Sinta 4 berdasarkan Keputusan Direktorat
Jenderal Penguatan Riset dan Pengembangan,
Kementerian Riset, Teknologi dan Pendidikan Tinggi
Republik Indonesia
Nomor: 23/E/KPT/2019. 08 Agustus 2019
https://jurnal.umk.ac.id/index.php/kredo/index

Nurjamal, Daeng dan Warta Sumirat. 2010. Penuntun Perkuliahan Bahasa Indonesia. Bandung: Alfabeta.

Olivia, Femi. 2008. Tools For Study Skills Teknik Membaca Efektif. Jakarta: Pt Gramedia.

Priyatni, Endah Tri. 2010. Membaca Sastra Dengan Ancangan Literasi Kritis. Jakarta: Pt Bumi Aksara.

Sugiyono. 2016. Metode Penelitian Kuantitatif Kualitatif dan $R \& D$. Bandung: Alfabel.

Sumardjo, Jakob dan Sain K.M. 2008. Apresiasi Kesastraan. .Pt.Gramedia Pustaka Utama

Sutopo, Maryati. 2008. Bahasa dan Sastra Indonesia. Palembang. 